\title{
An Exploratory Study on the Level of Trust Among Hungarian Food Manufacturer Companies
}

\author{
E. ERDEI
}

Károly Ihrig Doctoral School of Management and Business, University of Debrecen, edina.erdei@econ.unideb.hu

Abstract. The intensification of globalized economic competition is playing an increasingly important role in the lives of companies to determine their true position among their competitors. Food companies are of paramount importance because of their role and weight in the national economy. In Hungary, the food industry plays an important social and economic role and is a world leader in terms of employment and value added. Currently, there are nearly 1100 active food companies in Hungary, so it is worth examining the peculiarities of the role of trust between companies.

There are often contradictory statements in the literature about the effects of Industry 4.0 technologies and the trust placed in IT tools. Therefore, it is a relevant research question to examine whether the characteristics of the role of trust - e.g. staff, suppliers, IT tools and technologies, etc. as confidence levels can have a direct positive impact on the efficiency, profits, liquidity, etc. of the companies in question. development.

During the research, I analyzed the level of trust between the food trading companies, in which I discuss the trust within the industry within the company. My aim is to further enrich my previous research knowledge in this field.

\section{Introduction}

As a result of growing and global competition, executives have been forced to manage new technologies to improve the efficiency of companies. Of the various management methods, trust has received a great deal of attention for a number of reasons, as it is the basis for cooperation and networking. Trust is a prominent research topic of the 1980s, although there is no widely accepted concept or model for this term ever since.

Over the past decade, several researchers have published models based on a number of trusts. Many have made statements about the losses of lack of trust in business, while others have examined the dimensions, degree, forms, development and measurement of trust as to the benefits that companies can gain from having and building trust.

The aim of this study is to present the literature and models of trust based on organizational behavior, relationship value and business networking, where Georg Simmel's theory is the starting point. On the other hand, it is important to clarify the trust of food trading companies within the industry and within the company, and to examine its positive and negative effects on the efficiency and profitability of companies. 
The study gathers previous research results, as logistics and process approaches, as well as increased customer demand, have resulted in a focus on quality, flexibility and speed, which is influenced by inter-company and intra-company confidence.

Industry 4.0 is a company-wide and customer-supplier partnership approach that focuses on long-term, flexible, high-quality productivity. With the advent of Industry 4.0, it has also become important to analyze confidence in new IT tools and technologies.

\section{Literature review}

Despite qualitative and quantitative research, there is no widely accepted general definition of trust, many models illustrate it from different perspectives. The topic of trust appeared in both economics and marketing studies and became a popular topic in the 1980s.

Sociologists argue that trust can be defined as the basis for reduced social complexity (Luhmann, 1979), cooperation (Gambetta, 1988), social capital, individual risk-taking behavior (Coleman, 1988), order (Misztal, 1996).

Moorman et al. Define trust as relying on an exchange partner that you trust (Moorman et al., 1992). Sherman describes in his study that lack of trust is the cause of failure in establishing intercompany relationships (Sherman, 1992). However, trust lies not only in the good faith of the partner's actions, but also in his vulnerability to the partner (Morgan-Hunt, 1994). In addition, trust leads to consequences that improve productivity and efficiency. This means that trust can be defined as an attitude characterized by trust in the customer's trustworthiness. Trust is simply defined as the willingness to take risks (Mayer - Allen, 1995). Trust is usually a process that evolves over time, although it does not explicitly consider the temporal element (Walter et al., 2002). The essence of trust is to be able to adopt measures that deviate from habits and appropriateness, thereby reducing predictability (Huemer, 2004).

Andaleeb believes that trust depends on motivation and perceptions, and that the development of trust can only be explained by considering another dimension: the ability of the exchange partner, or rather the perception of this competence (Andaleeb, 1992). Your model represents a paired approach and examines how partners perceive each other. Based on this research, it identifies the different levels of trust that can be found in market relationships: trust attachment, hopeful trust, unstable trust, and distrust.

Besides Andaleeb, Ganesan's model is perhaps the most frequently cited model of trust. Ganesan proposes two dimensions of trust, very similar to those identified by Andaleeb (1992): (a) credibility, which depends on the credibility of the buyer with the supplier to carry out his task efficiently and reliably; (b) benevolence on the basis of the belief of the buyer that the supplier will act with the intent to the benefit of the buyer (Ganesan, 1994).

Some researchers see communication as a consequence of trust (Dwyer et al., 1987), while others see communication as a determinant of trust (Selnes, 1998). From a dynamic point of view, the 
circular and repetitive relationship between communication and trust must be assumed (Anderson - Weitz, 1989; Anderson - Narus, 1990).

Trust exists when a company thinks that its partner is honest and kind (Kumar et al. 1995). In their research, Kumar and colleagues tried to measure a system of 10 elements based on trust. Five items examined how honest and trustworthy the partner was; another five items looked at the responding firm's belief that the partner was taking into account the company's interests or well-being.

According to Mayer et al., Perceived reliability and trust behavior are determinants and consequences of trust (Mayer et al., 1995). According to the authors, there are three factors that lead a subject to trust his partner (that is, the three components of reliability): the ability associated with the partner's competence to deliver what the trustor expects; integrity, which refers to the fact that the partner is guided by principles acceptable to the agent; benevolence that shows the trustee's intention to do everything for the lender.

Huemers' dynamic model of resource activity moves forward and focuses on resources, so he tries to integrate trust into practice and seeks the direct benefits of trust in business relationships. In theory, the goal is to fulfill the company's strategy. Participants need sufficient resources so that in the first cycle, the buyer and seller can recognize, learn routines and procedures while building trust. Understanding and following written and unwritten rules is a major goal for both of us during this period. In the second cycle, they mobilize their recent trust with the involvement of business partners, trusting in their ability to redefine their roles and relationships, and this positively and measurably improves their performance and means long-term relationships. (Huemer, 2001).

Csabina and his co-authors also examined the development of a level of trust. He found that the more tailor-made, unique the product in question is, the higher the inter-company business confidence (Csabina et al., 2001). According to Baldasz's research, $46 \%$ of Hungarian mechanical engineering companies, $29 \%$ of raw materials and chemical companies, and $27 \%$ of nonmanufacturing companies are characterized by high levels of trust (Kopasz, 2003).

Another study found that the rate of relationship failure is more than 50\% (Spekman et al., 2000). In a 2003 article by Moberg et al., 55\% of UK companies were disappointed in partnerships within three years (Moberg et al., 2003). In Huemer's view, the parties' mutual trust has raised business partners from previous routines and procedures to far less predictable ones.

Ulaga and Eggert define the benefits of relationship value in terms of products, services, knowhow exchange and social relationships (Ulaga - Egger, 2005). Mandyas and Simon show three levels of exchange: exchange, connection, and network. In the case of value types, their model examines economic value (utility) and social value (motivation). In this article, we emphasize the relationship and network levels of social values from their theory. So the social values at the level of relationships are: smoothing relationships, security, supplier competence. While network-level social values include: a) "relationship building", b) "supplier / seller position in their industry", c) 
"supplier / seller non-market strategy" (Mandják - Simon, 2007). We believe that building trust can improve these social values, both in relationships and in supply chains.

Hámori concluded that $63 \%$ of the respondents found low willingness to cooperate among economic operators (Hámori et al., 2007). In addition, if economic agents do not trust each other, when a problem arises, no matter how small, they try to enforce their claims, which may involve high costs (Török, 2007).

Authors Szepesi and Szabó-Morvai, who surveyed 700 Hungarian companies in 2009, found that personal relationships determine trust, as business partners primarily regard honest business behaviors as important, and friendship less important. In their opinion, friendship does not make a partner reliable (Szepesi - Szabó-Morva, 2009).

According to Hodosi's research, trust also has a cost-reducing role, as it claims that increased trust contributes to efficient operation, thereby reducing transaction costs. Other researchers show trust through innovation (Hodosi, 2011). Confidence can reduce the risks of innovation, so more and more companies invest in new technologies, ultimately resulting in increased competitiveness (Gelei, 2014). Managers consider the information they receive from a reliable source, known persons (Keszey-Biemans, 2017) to be of better quality.

While food manufacturer companies in Hungary are thinking about building trust in the long term, light industry, commodity and chemical companies have a shorter-than-average outlook, which is why trust in the latter industry is low. Customer confidence is completely different from one industry to another. If the economy increases trust between partners, so does the performance of the economy.

Lack of trust between trading partners increases transaction costs to an unacceptably high level. Creating value-adding activities with such partners becomes virtually impossible and supply chain tools used to improve efficiency, productivity (such as vendor-managed inventory, crossdocking and collaboration forecasting, planning and uploading) are ultimately ineffective. When measuring trust, variables such as communication, information exchange and reputation are often used, although trust can sometimes be used as a substitute for information.

With reference to our literature review on the variables of trust, I believe that these factors can improve trust and, through trust, indirectly and positively influence the value of relationships in Hungarian business practice.

\section{Research material and methodology}

The primary purpose of this study is to examine how trust influences companies' competitiveness and business performance. In my research, I consider it important, beyond inter-company relationships, to process and evaluate trust in technology, which has become one of the major central issues of our time.

The first step in primary data collection is the preparation of a questionnaire for food manufacturing companies. During the research I asked the food manufacturer companies 
belonging to the 10th group based on the TEÁOR number. The questionnaire survey was conducted in the fourth quarter of 2019, typically through professional events and personal inquiries.

The first part of the questionnaire provides information on the geographical location of companies, their ownership structure, their legal form, their role in the sector and the number of employees. After that, I asked further questions about the confidence of companies within the industry and within the company, and I also touched on the issues of trust in new technologies and innovations. The professional basis for the preparation of the questionnaire is provided by the literature research.

During the literature research, secondary information was collected mainly through the processing of international and partly domestic literature. The reason for the predominance of international literature is that the use of Industry 4.0 and Industry 5.0 technologies can be identified as an unexplored area in the domestic literature, and the creation of different models is also scarce. In addition to literature related to the research, additional information is provided by periodicals, studies and professional discussion papers on the topic. I consider complex examination to be important, so it is reasonable to explore the relationships as accurately as possible.

During the processing of the collected data I applied statistical methods. Questionnaire statements were rated on a 1 to 5 Likert scale by respondents. The essence of the method is that respondents evaluate different statements on a scale formed between two extremes. Among the descriptive statistical methods, the mean and the minimum and maximum values representing the standard deviation were used primarily.

The ultimate goal of the research is to enrich the development of IT, logistics and economics, and propose solutions to real corporate trust issues.

\section{Results}

During the research I asked the food manufacturer companies belonging to the 10th group based on the TEÁOR number. The questionnaire survey was conducted in the fourth quarter of 2019, typically through professional events and personal inquiries. A total of 78 companies completed the research questionnaire. Figure 1 illustrates the distribution of respondents by county and employment:

\begin{tabular}{lccccc}
\hline $\begin{array}{l}\text { County / } \\
\text { Number of employees (people) }\end{array}$ & $\mathbf{1 - 9}$ & $\mathbf{1 0 - 4 9}$ & $\mathbf{5 0 - 2 4 9}$ & $\mathbf{2 5 0}+$ & Summary \\
\hline Bács-Kiskun county & 3 & 9 & 6 & 3 & $\mathbf{2 1}$ \\
Békés county & & 6 & & & $\mathbf{6}$ \\
Borsod-Abaúj-Zemplén county & & 3 & & & $\mathbf{3}$ \\
Csongrád county & 3 & & & & $\mathbf{3}$ \\
Fejér county & & & & 3 & $\mathbf{3}$
\end{tabular}




\begin{tabular}{|c|c|c|c|c|c|}
\hline Győr-Moson-Sopron county & & 6 & 3 & & 9 \\
\hline Hajdú-Bihar county & & 6 & & 3 & 9 \\
\hline Heves county & & 3 & & & 3 \\
\hline Komárom-Esztergom county & & 3 & & & 3 \\
\hline Pest county & & 6 & 3 & & 9 \\
\hline Somogy county & & & 3 & & 3 \\
\hline Tolna county & & 3 & & & 3 \\
\hline Vas county & 3 & & & & 3 \\
\hline Total & 9 & 45 & 15 & 9 & 78 \\
\hline
\end{tabular}

Table 1. Distribution of respondents by county and number of employment

Source: Own research, 2020.

Most of the respondents are companies with 10-49 employees, which accounted for almost $60 \%$ of our sample. The majority of the respondents deal with meat processing and the production of bakery products and pasta, but also entrepreneurs from the processing of fruit and feed.

\subsection{Industry and company confidence}

Looking at respondents' industry and company confidence, we find that most of them trust their business partners. When evaluating industry responses, there was no company that had marked high levels of distrust among its partners. When examining trust between business partners, I divided the partners into three parts: buyers, suppliers and food manufacturers like the company. Figure 1 shows that companies tend to trust their partners. The relationship between companies and their customers is based on a high level of trust, followed by a level of trust with their suppliers, followed by confidence in a similar food manufacturer company. Most of the answers were given to the existence of trust for all three types of partners. Not surprisingly, 6 replies were received, suggesting that companies do not trust similar food manufacturer companies, so they can be seen as competing with other food manufacturer companies.

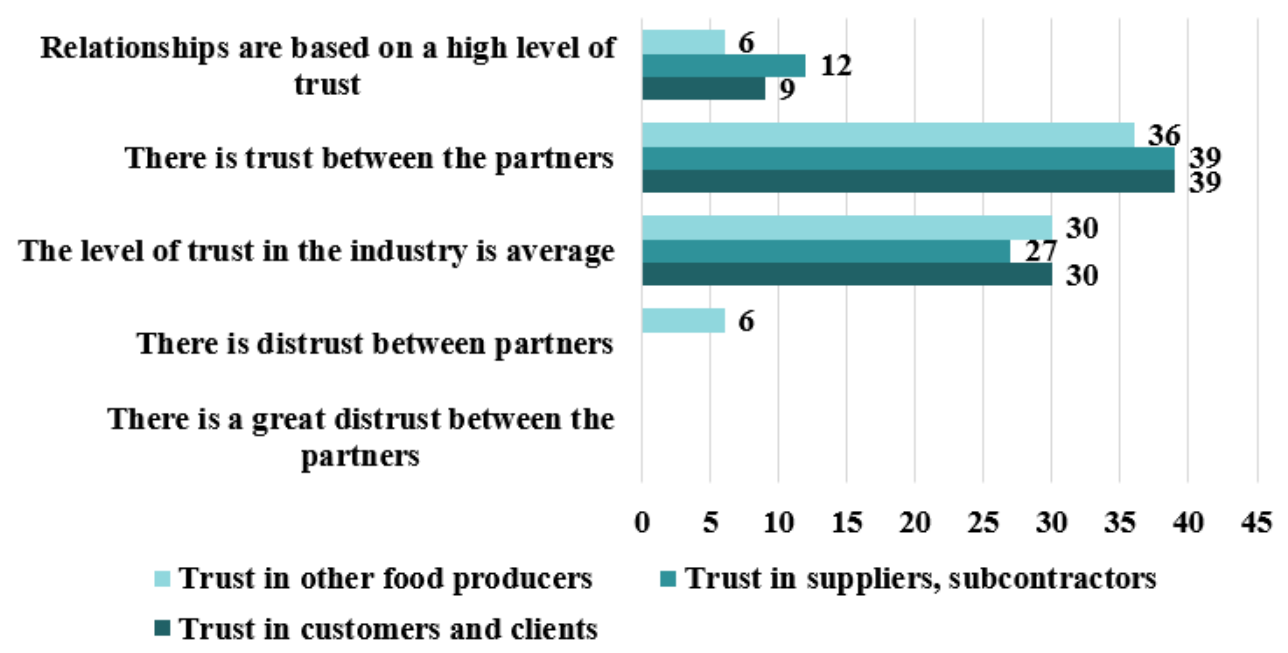

Figure 1. Investigation of trust between companies (customers, suppliers, other food producers). Source: Own research, 2020. 
In my questionnaire, respondents using a five-point Likert scale had to answer the question of appreciating the general climate of trust between employees within the company (Figure 2). The majority of respondents, $62 \%$, found high or very high levels of trust among employees, with only a few responding to low levels of trust. Respondents from a total of 6 companies believe that trust within the company is low. These companies employ more than 50 people.

Examining the number of employees, I came to the conclusion that companies employing more people are less likely to trust employees than companies with fewer employees. In addition, companies with less than 50 employees have less confidence in suppliers, subcontractors, but have a high level of confidence in small food manufacturer companies.

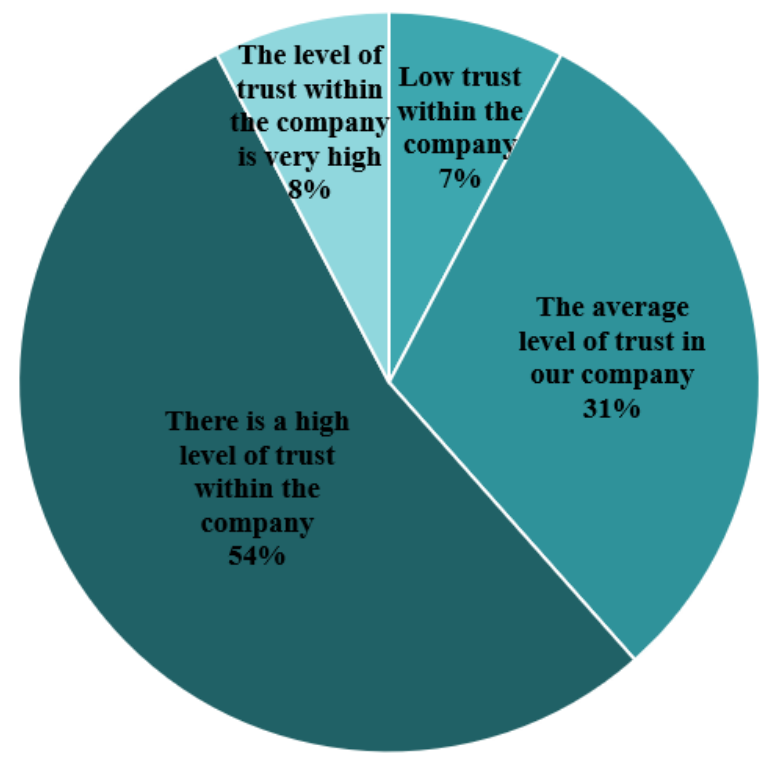

Figure 2. Assessing the general climate of trust within the company.

Source: Own research, 2020.

\subsection{Trust in innovation}

In my questionnaire, the fillers had to answer the question of their degree of trust in IT tools in the following areas: manufacturing, process management, sourcing, sales and marketing, human resources, finance and accounting, risk analysis, controlling. $70 \%$ of respondents trust certain areas of a company, while the remaining 30\% trust it on average or below. Risk management and finance and accounting are areas in which respondents are not trusted at all. Human resources and process management are among the areas where respondents are less trusted. Purchasing and manufacturing are among the areas in which respondents are most confident. 


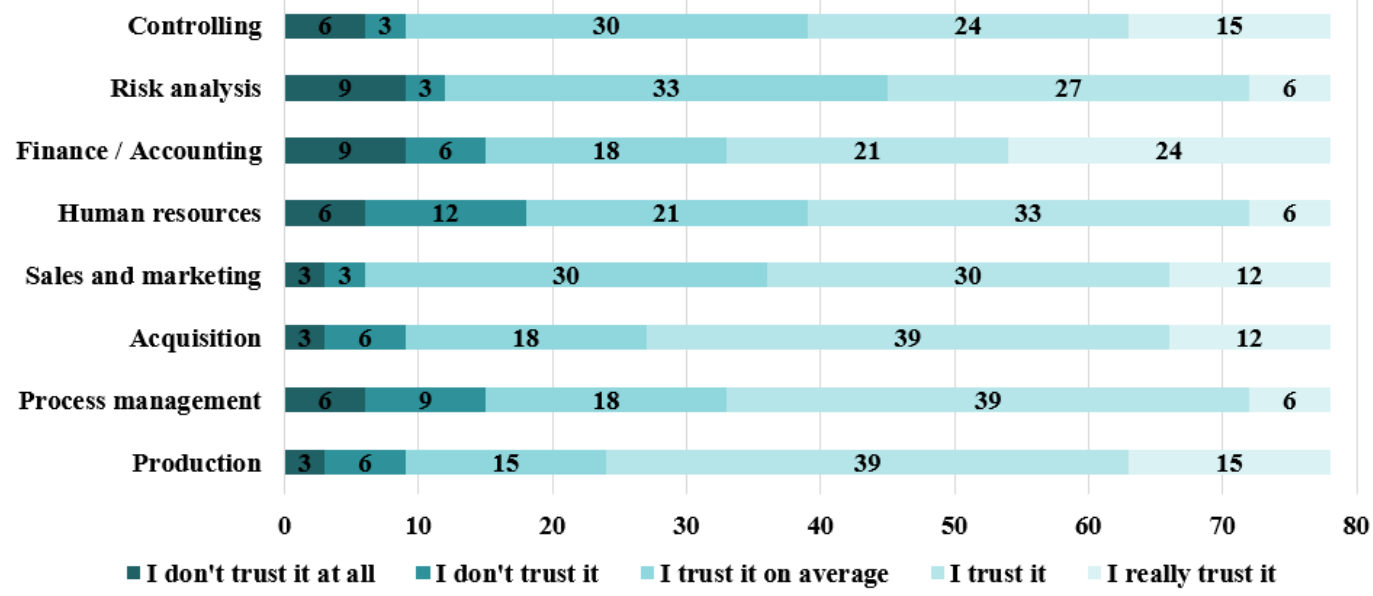

Figure 3. The degree of trust in IT tools in each area.

Source: Own research, 2020.

Figure 4 shows how trusted companies are in the use of IT software. The value in light blue indicates how many "I don't trust it at all." answers for that IT program. Figure 4 shows that total quality management is a tool that has received 0 "I don't trust it at all" answers. The value marked in dark blue indicates how many "I really trust it." answers were received for that IT program. Out of the 11 IT tools, the production management system received the most " I really trust it." answers. The least trust is in cloud-based services and most respondents trust the production management system, followed by full-scale quality management. Robotic devices show the majority of respondents trust, but they do not trust in-machine communication and RFID technology.

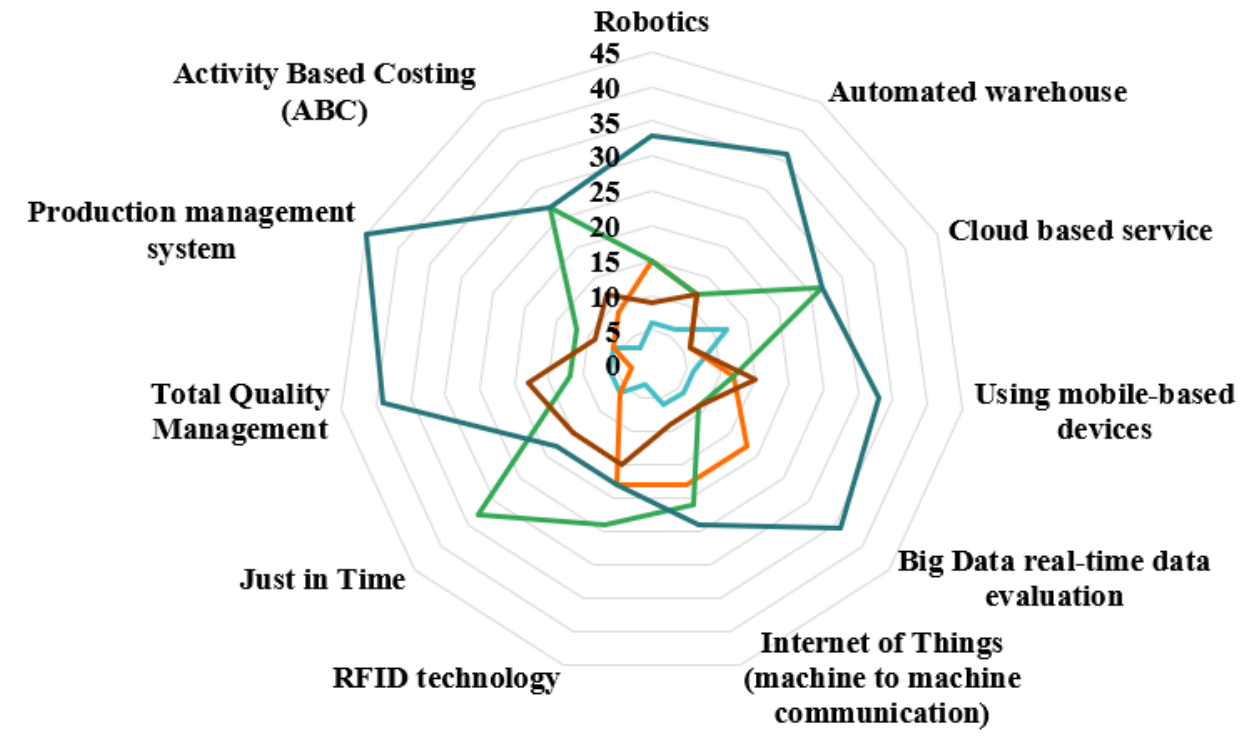

- I don't trust it at all - I don't trust it - I trust it on average $-I$ trust it - I really trust it

Figure 4. The degree of trust when using programs.

Source: Own research, 2020. 
In defining industry confidence, in-company confidence, and in evaluating trust in innovation, I found it important to examine whether there is a significant difference between male and female respondents. When evaluating the Likert scale 1-5, the answers marked with 3 were considered neutral. Answers below 3 can be called mistrust, and answers above 3 can be called confidential. Table 2 shows that male respondents are much more likely to trust their business partners and in-house colleagues than female respondents. When evaluating confidence in innovation, it can be seen that more than twice as many male respondents responded that they do not trust these IT tools.

\begin{tabular}{lcc}
\hline Factors & $\begin{array}{c}\text { Number of male } \\
\text { responses }\end{array}$ & $\begin{array}{c}\text { Number of female } \\
\text { responses }\end{array}$ \\
\hline Trust within the company - yes (4,5) & 29 & 19 \\
Trust within the company - neutral (3) & 19 & 11 \\
Trust within the company - no (1,2) & 0 & 0 \\
Trust between business partners - yes (4.5) & 29 & 19 \\
Trust between business partners - neutral (3) & 14 & 10 \\
Trust between business partners - no (1,2) & 5 & 1 \\
Confidence in innovation (11 factors) - yes (4.5) & 183 & 132 \\
Confidence in innovation (11 factors) - neutral (3) & 92 & 61 \\
Confidence in innovation (11 factors) - no (1,2) & 109 & 47 \\
\hline
\end{tabular}

Table 2. Evaluate the confidence of male and female respondents in the company, within the business and in innovation.

Source: Own research, 2020.

\section{Conclusions}

When establishing a relationship, a high level of trust can influence the quality and quantity of communication between the parties and, consequently, the understanding of customer expectations and the correct design of the performance expected by the company.

Maintaining trust within and between companies is very important as lack of it can have consequences: long contracts, increased transaction costs, losses due to non-cooperation, slowing of economic growth, loss of productivity and loss of efficiency.

Commitment and trust are central to contributing to cooperative behavior, reducing transaction costs, improving productivity and efficiency, and increasing the frequency of information exchange, thereby reorganizing business relationships and increasing revenue. Analyzing the positive and negative effects of trust is extremely important, and companies need to consider how much they can trust their business partners, and the benefits and disadvantages of maintaining trust. 
Regarding business partners, the answers show that there is trust in customers and suppliers, but the least trusted are the fillers in the food manufacturer companies as they are considered to be their competitors. The majority of respondents, $62 \%$, found high or very high levels of trust among employees, with only a few responding to low levels of trust. Examining the number of employees, I came to the conclusion that companies with more than 50 employees have less confidence in their employees than companies with fewer employees. Male respondents are much more likely to trust their business partners and in-house colleagues than female respondents.

Risk management and finance, accounting are areas in which respondents are not trusted at all, and human resources and process management are areas in which respondents are less trusted.

Furthermore, the research also covers the use of IT programs. During my research I examined the trust in the following IT tools: Robotics, Automated warehouse, Cloud based service, Using mobilebased devices, Big Data real-time data evaluation, Internet of Things, RFID technology, Just in Time, Total Quality Management, Production management system, Activity Based Costing. In addition, the research reveals that companies have the least trust in cloud-based services and that RFID technology is also considered dangerous. Among the tested technology tools, the majority of respondents consider the production management system to be reliable, as well as full quality management.

Managing business-to-business information and maintaining a business transaction is vital if you want to build long-term partnerships and be strategic from the point of view of our competitiveness. Participation, information sharing and quality are the defining features of communication between partners.

Collective optimization, sharing and collaboration are key to success in supply chains. Therefore, trust between partners in the information system between organizations is essential. However, companies are afraid to share information across organizational boundaries. Therefore, trust between partners with an information system between organizations is essential.

\section{Acknowledgments} PROGRAM OF THE MINISTRY FOR INNOVATION AND TECHNOLOGY.

\section{References}

[1] Andaleeb, S.S. (1992): The trust concept: research issues for channel distribution, Research in Marketing, vol.11, pp.1-34.

[2] Anderson E., Weitz B. (1989): Determinants of continuity in conventional industrial channel dyads, Marketing Science, vol.8 Fall, pp.310-323. 
[3] Anderson, J.C., Narus, J.A. (1990): A model of distributor firm and manufacturer firm working partnerships, Journal of Marketing, 54 (1), p.42-58.

[4] Dwyer F.R., Schurr P.H., Oh S. (1987): Developing Buyer-Seller Relationships, Journal of Marketing, n.5 April, pp.11-27

[5] Coleman, J. S. (1988): Social Capital in the Creation of Human Capital', American Journal of Sociology 94: S95-S120.

[6] Csabina Z., Kopasz M., Leveleki M. (2001): A szerződéses bizalom a hazai feldolgozóipari vállalatok üzleti kapcsolataiban. Szociológiai Szemle, 1. sz.

[7] Gelei A. (2014): Az üzleti kapcsolatok irányítása - fókuszban a bizalom. Köz-gazdaság, 9 (2). pp. 85-99.

[8] Gambetta, D. (1988): Trust: Making and Breaking Co-operative Relations. Oxford: Basil Blackwell.

[9] Ganesan, S. (1994): Determinants of Long-Term Orientation in Buyer-Seller Relationships, Journal of Marketing, 58 (April), p.1-19.

[10] Hámori B., Szabó K., Derecskei A., Hurta H., Tóth L. (2007): Versengő és kooperatív magatartás az átalakuló gazdaságban (Competitive and Cooperative Behaviour in Transition Economy). Közgazdasági Szemle.

[11] Hodosi, A. (2011): A bizalom mint költségcsökkentő tényező. Competitio,10. 1.: p. 1-12.

[12] Huemer, L. (2001): Resource - Activity Dynamics: On the Mobilization of Trust and the Essence of Trusting, 17th IMP conference, Oslo, Norway

[13] Huemer, L. (2004): Activating trust: the redefinition of roles and relationships in an international construction project, International Marketing Review Vol. 21 No. 2, pp. 187 201

[14] Keszey, T., Biemans, W. G. (2017): Trust in marketing's use of information from sales: The moderating role of power. Journal of Business \& Industrial Marketing. 32 (2) 258-273.

[15] Kopasz, M. (2003): Jó szándék és kompetencia - avagy a bizalom két összetevője egy magyarországi vállalati felmérés tükrében. Erdélyi társadalom - 3. évfolyam 2. szám: p. 7189.

[16] Kumar, N., Sheer, L.K., Steenkamp, J-B.E.M (1995): The Effects of Perceived Interdependence on Dealer Attitudes, Journal of Marketing Research, 32 (August) p.348-56

[17] Mandják T., Simon J. (2007): First Steps of the Empirically Test of the Integrated Business Relationship Value Model, in: IMP Conference proceedings, Manchester, Great Britain.

[18] Mayer, J.P., N.J. Allen (1995): Testing the Side-Bet Theory of Organizational Commitment: Some Methodological Considerations. Journal of Applied Psychology, (69:3), 1984, pp. 372378.

[19] Misztal, B.A. (1996): Trust in Modern Societies. Cambridge: Polity Press. 
[20] Moberg, C.P, T.W. Speh, T.L. Freese (2003): SCM: Making the Vision a Reality. Supply Chain Management Review, September-October, pp. 34-39.

[21] Moorman, C., Zaltman, G., Deshpandé, R. (1992): Relationships Between Providers and Users of Market Research: The Dynamics of Trust Within and Between Organisations. Journal of Research in Marketing, 29(August): S. 314-328.

[22] Morgan R.M., Hunt S.D. (1994): The commitment-trust theory of relationship marketing, Journal of Marketing, vol.58 n.3 July, pp.24-38.

[23] Selnes F. (1998): Antecedents and consequences of trust and satisfaction in buyer-seller relationships, European Journal of Marketing, vol.32, pp.305-322.

[24] Sherman, S. (1992): Are Strategic Alliances Working? Fortune, September 1992, pp. 77-78.

[25] Spekman, R. E., Isabella, Lynn A., MacAvoy, Thomas C. (2000): Alliance Competence: Maximizing the Value of Your Partnerships. New York: John Wiley.

[26] Szepesi B., Szabó-Morvai Á. (2009): A bizalom infrastruktúrája - a vállalkozások együttmúködésének biztosítékai Magyarországon. Közjó és Kapitalizmus Intézet, 17. Műhelytanulmány

[27] Török Á. (2007): A versenyképesség egyes jogi és szabályozási feltételei Magyarországon. Közgazdasági Szemle, LIV. évf.: p. 1066-1084.

[28] Ulaga, W., Eggert, A. (2005): Relationship Value in Business Markets: The Construct and its Dimensions, Journal of Business-to-Business Marketing, 12(1), pp. 73-99.

[29] Walter, A., Hölzle, K., Ritter, T. (2002): Relationship functions and customer trust as value creators in relationships: A conceptual model and empirical findings for the creation of customer value. $18^{\text {th }}$ IMP Conference, Dijon, France 